\title{
THE LYMPHOCYTE TRANSFORMATION TEST AND GOLD HYPERSENSITIVITY
}

\author{
BY \\ EVELYN J. DENMAN AND A. M. DENMAN \\ Medical Research Council Rheumatism Research Unit, Canadian Red Cross Memorial Hospital, \\ Taplow, Maidenhead, Berks.
}

The Empire Rheumatism Council's controlled trial (1960) showed that gold salts benefit patients with rheumatoid arthritis. However, side-effects still occur with this treatment despite regular blood counts and urine examinations and, although the incidence of severe reactions has probably been reduced by careful attention to the dose and number of injections given, serious haematological complications are still encountered (Saphir and Ney, 1966). It is widely believed that toxicity from gold therapy is immunologically determined, but so far there has been little convincing evidence to prove this assumption.

Blast transformation of peripheral blood lymphocytes after their exposure in vitro to an antigen to which the donor has become sensitized has been used as a test for drug hypersensitivity (Vischer, 1966; Sarkany, 1967). We report here experiments in which the peripheral blood lymphocytes of patients with severe gold toxicity responded to in vitro challenge with Myocrisin. The results provide direct evidence that gold hypersensitivity is immunologically determined and suggest a possible method for predicting the likelihood of toxicity occurring in individual patients.

\section{Material and Methods \\ Peripheral Blood Cultures and Their Analysis}

The methods used in this laboratory have already been described (Vischer, 1966; Vischer and Stastny, 1967); $20 \mathrm{ml}$. blood were obtained in 10 units preservative-free heparin (Evans Medical Ltd.), the red blood cells were allowed to sediment at $37^{\circ} \mathrm{C}$. for 30 to 60 minutes, and the leucocyte-rich plasma was withdrawn. Since initial experiments with standard antigens such as tuberculoprotein (PPD) and diphtheria toxoid produced responses of equal magnitude in cultures consisting of unseparated leucocytes and in those of mononuclear cells freed from

*Radiochemical Centre, Amersham. polymorphs and phagocytic cells, all tests were carried out with unseparated leucocytes. Each culture was adjusted to contain $2 \times 10^{6}$ mononuclear cells and the final volume was made up to $5 \mathrm{ml}$. with Parker "199" Medium (Glaxo) containing $100 \mu \mathrm{g} . / \mathrm{ml}$. streptomycin and 200 units $/ \mathrm{ml}$. penicillin. When the patient's plasma constituted less than 20 per cent. of the final volume, foetal bovine serum (Flow Laboratories Ltd.) was added to achieve this proportion. Foetal calf serum from this source never showed any stimulatory activity in control cultures.

The antigens and drugs described below were added on the first day of culture. $5 \mu \mathrm{c}$. tritiated thymidine ( $\mathrm{H}^{3}$ thymidine)* was added on the 4th and 5th days of culture and the cells were harvested on the 6th day. The specific activity of each batch of $\mathrm{H}^{3}$ thymidine was adjusted to $80 \mathrm{mc}$. per m.mole with unlabelled thymidine. The cells were washed with ice-cold isotonic saline followed by freezing and thawing. The nucleic acid residue was isolated by successive extractions with $0.9 \mathrm{M}$ trichloracetic acid, 44 per cent. dimethylsulphoxide in phosphate buffered saline, and cold 85 per cent. ethanol. The final precipitate was dissolved in $1 \mathrm{ml} .0 \cdot 1 \mathrm{~N}$ sodium hydroxide and was counted in $10 \mathrm{ml}$. Bray's solution (Bray, 1960) with added Cab-O-Sil in a Tracerlab liquid scintillation counter. The results are mean values for duplicate cultures.

At the time of harvesting, autoradiographs were prepared from the cultures using Kodak "AR10" stripping film and were exposed for 7 days. The films were stained with May-Grünwald Giemsa and were coded so that the examiner was unaware of their identity. The number of labelled blast cells was counted in a minimum of 1000 cells. An example of labelled blast cells is shown in Fig. 1 (opposite).

\section{Addition of Drugs and Antigens}

Cultures from each patient always included unstimulated "baseline" cultures to which no antigen was added and cultures containing phytohaemagglutinin (PHA) (Difco) $0 \cdot 1 \mathrm{ml}$. per culture. $\mathrm{H}^{3}$ thymidine was added to PHA cultures after 24 hours and the cells were harvested after 72 hours. All cultures were set up in 


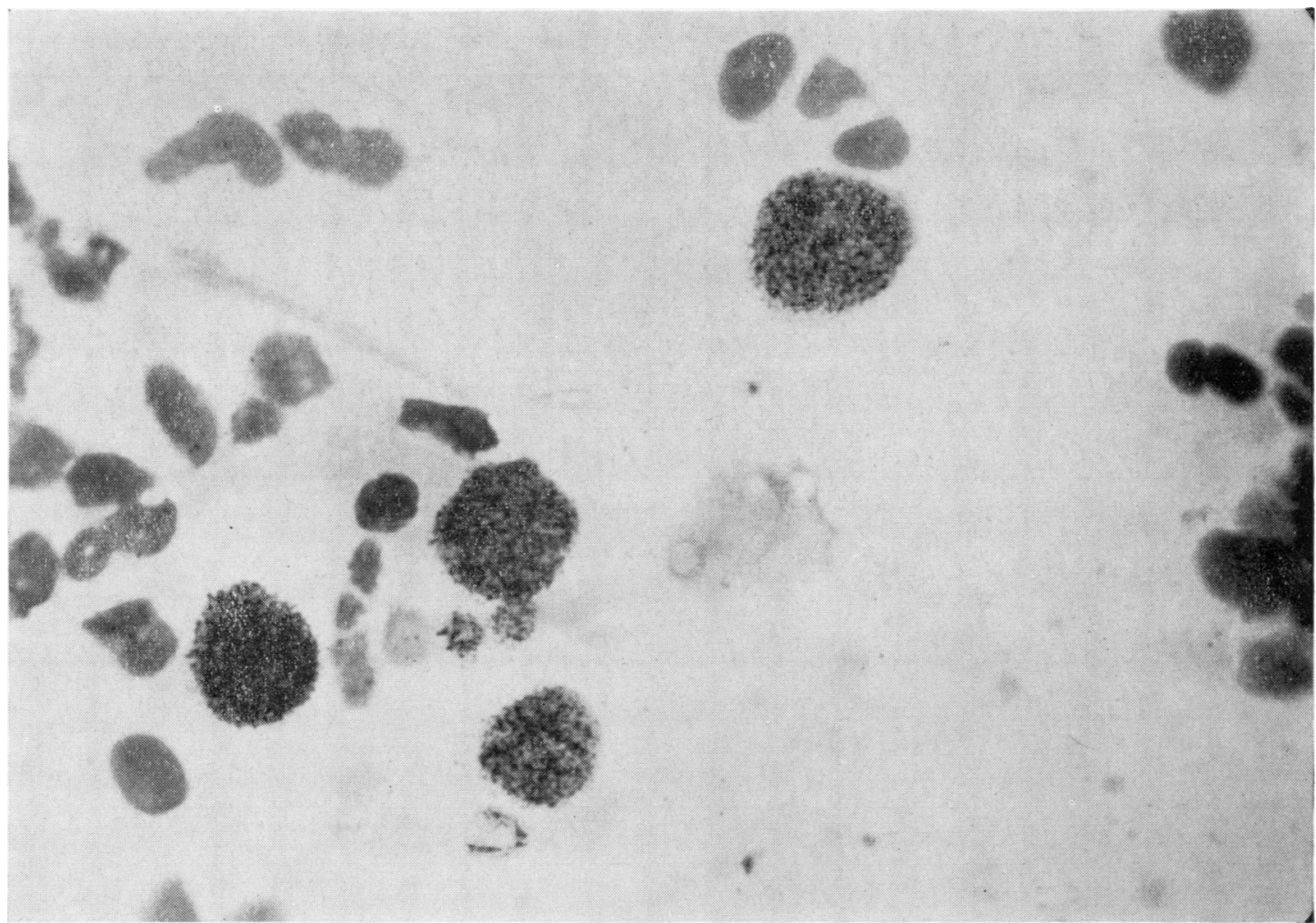

Fig. 1.-Autoradiograph obtained from culture exposed to tuberculoprotein (PPD) for 5 days, showing labelled transformed cells. $\times 600$.

duplicate. The concentrations of drugs and antigens added to the cultures are listed in Table I. Cultures from all patients were challenged with Myocrisin, phenylbutazone, streptokinase, and PPD; the other agents in Table I were added to cultures from the majority of patients depending upon the number of cells available.

TABLE I

CONCENTRATION OF DRUGS OR ANTIGENS ADDED TO CULTURES

\begin{tabular}{|c|c|c|}
\hline Drug or Antigen & \multicolumn{2}{|c|}{$\begin{array}{l}\text { Amount added per } 5 \mathrm{ml} . \\
\text { Cultures }\end{array}$} \\
\hline Streptokinase* & \multicolumn{2}{|c|}{$10 \cdot 0$ units } \\
\hline Tuberculoprotein (PPD)† & \multicolumn{2}{|c|}{$5 \mu \mathrm{g}}$. \\
\hline $\begin{array}{l}\text { Lipopolysaccharide B } \\
\text { S. typhi-murium (Endotoxin) } \ddagger\end{array}$ & \multicolumn{2}{|c|}{$0.01 \mu \mathrm{g}$} \\
\hline Sodium Aurothiomalate "Myocrisin" & $10 \mu \mathrm{g}$ & $20 \mu \mathrm{g}$ \\
\hline Phenylbutazone “Butazolidin" & $10 \mu \mathrm{g}$ & $20 \mu \mathrm{g}$ \\
\hline Indomethacin "Indocid" & $10 \mu \mathrm{g}$ & $20 \mu \mathrm{g}$ \\
\hline Chloroquine Sulphate "Nivaquine" & \multicolumn{2}{|c|}{$10 \mu \mathrm{g}}$. \\
\hline Salicylates “Aspirin" & \multicolumn{2}{|c|}{$10 \mu \mathrm{g}}$. \\
\hline
\end{tabular}

*Lederle

tEvans Medical Ltd.

$\vdots$ Difco.

\section{Patient Groups}

The patients in this study were all attending the M.R.C. Rheumatism Research Unit at Taplow with one exception who was an in-patient at Hammersmith Hospital, London. Lymphocyte stimulation tests were performed on four groups of patients.

Group A.-This consisted of six patients with thrombocytopenia, agranulocytosis, or aplastic anaemia, which in five cases developed during Myocrisin therapy. The sixth patient had received gold injections 12 years previously but was taking phenylbutazone when aplastic anaemia ensued. Further details of these patients are given in Table II (overleaf).

GROUP B.-There were six patients in this group with skin rashes putatively attributed to gold whose clinical details are given in Table III (overleaf).

Group C.-This comprised twelve patients, eleven with classical rheumatoid arthritis and one with Still's disease, who had received varying amounts of Myocrisin without clinical or haematological evidence of hypersensitivity. These patients had received a total of 260 to $1000 \mathrm{mg}$. Myocrisin at the time of testing; they were tested at intervals during and immediately after this 
CLINICAL FEATURES OF SIX PATIENTS WITH RHEUMATOID ARTHRITIS WF̈O

\begin{tabular}{|c|c|c|c|c|c|c|}
\hline Patient No. & $\begin{array}{l}\text { Age } \\
\text { (yrs) }\end{array}$ & Sex & $\begin{array}{l}\text { Disease } \\
\text { Category }\end{array}$ & $\begin{array}{l}\text { Duration } \\
\text { of Disease } \\
\text { (yrs) }\end{array}$ & $\begin{array}{l}\text { Total Myocrisin up to Time of } \\
\text { Toxic Reaction } \\
\text { (mg.) }\end{array}$ & Other Drugs at Time of Tes \\
\hline 1 & 38 & $\mathrm{~F}$ & Classical & 6 & $167 \cdot 5$ & Indocid Chloroquine Salicyl \\
\hline 2 & 26 & $\mathbf{F}$ & Classical & 5 & $970 \cdot 0$ & Indocid Salicylates \\
\hline 3 & 53 & $\mathbf{F}$ & Classical & 20 & $1,005 \cdot 0$ & Indocid Salicylates \\
\hline 4 & 56 & $\mathbf{F}$ & Classical & 27 & $807 \cdot 5$ & Prednisone BAL \\
\hline 5 & 55 & $\mathbf{F}$ & Classical & 28 & 10 injections 12 years previously & $\begin{array}{c}\text { Phenylbutazone } 4 \text { yrs } \\
\text { Indocid Salicylates }\end{array}$ \\
\hline 6 & 48 & $\mathbf{F}$ & Definite & 4 & $869 \cdot 0$ & Prednisone BAL \\
\hline
\end{tabular}

*At the time of testing; 35 days previously, onset of purpura associated with a blood film showing severe neutropenia and thrombocytopenia.

CLINICAI FEATURES OF SIX PATIENTS WITH SRM

\begin{tabular}{|c|c|c|c|c|c|c|}
\hline Patient No. & $\begin{array}{l}\text { Age } \\
\text { (yrs) }\end{array}$ & Sex & Disease & $\begin{array}{l}\text { Duration } \\
\text { of Disease } \\
(y \mathrm{rs})\end{array}$ & Description of Skin Rash & $\begin{array}{l}\text { Total Myocrisin up } \\
\text { Time of Rash } \\
\text { (mg.) }\end{array}$ \\
\hline 1 & 56 & $\mathbf{M}$ & Classical RA & 2 & $\begin{array}{l}\text { Itchy plaques on legs, } \\
1 \text { week }\end{array}$ & $1,000 \cdot 0$ \\
\hline 2 & 38 & $\mathbf{M}$ & Classical RA & 3 & $\begin{array}{l}\text { Macular rash left hand, } \\
1 \text { week }\end{array}$ & $725 \cdot 0$ \\
\hline 3 & 49 & $\mathbf{M}$ & Classical RA & 10 & $\begin{array}{l}\text { Generalized pruritus, } \\
1 \text { week }\end{array}$ & 575.0 을 \\
\hline 4 & 13 & $\mathbf{M}$ & Still's Disease & 1 & $\begin{array}{l}\text { Erythematous rash on wrist } \\
\text { and chest, } 1 \text { week }\end{array}$ & $50 \cdot 0$ \\
\hline 5 & 65 & $F$ & Classical RA & 4 & $\begin{array}{l}\text { Erythematous rash on legs, } \\
\text { arms, and trunk, } 1 \text { week }\end{array}$ & $27 \cdot 5$ \\
\hline 6 & 54 & $\mathbf{M}$ & Classical RA & 5 & Facial erythema, 1 month & $775 \cdot 0$ \\
\hline
\end{tabular}

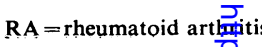

course of treatment. Their age distribution and the severity of their disease were comparable to that in the other groups.

Group D.-This comprised six patients with rheumatoid arthritis who had never received gold.

\section{Results}

Criteria for Positive Lymphocyte Transformation Tests

Preliminary experiments, both in patients with rheumatoid arthritis and in healthy controls, using a wide range of antigenic stimuli showed that there was a good correlation between the two methods of assessing lymphocyte transformation, namely liquid scintillation counting and analysis of autoradiographs (Fig. 2, p. 586).

A stimulated culture giving counts per minute two or more times greater than baseline cultures from the same patient was regarded as a positive response, and autoradiographs showed a proportionate increase in the number of labelled blast cells in the same culture. Moreover, responses of this magnitude were produced by PPD or streptokinase in cultures from patients who had given positive skin tests to these agents. Cultures which responded to challenge with Myocrisin or phenylbutazone did so equally well with both concentrations employed (Table I). PHA produced a 50-fold or greater response in cultures from patients in all groups. 
II

DEVELOPED HAEMATOLOGICAL COMPLICATIONS AFTER TREATMENT WITH MYOCRISIN

\begin{tabular}{|c|c|c|c|c|c|}
\hline \multirow{3}{*}{$\begin{array}{c}\text { Time of Test in relation } \\
\text { to Drug Reaction } \\
\text { (days) }\end{array}$} & \multirow{3}{*}{ Outcome } & \multicolumn{4}{|c|}{ Blood Count at Time of Test } \\
\hline & & \multirow[b]{2}{*}{$\stackrel{\mathrm{Hb}}{(\mathrm{g} . / 100 \mathrm{ml} .)}$} & \multicolumn{2}{|c|}{ WBC } & \multirow[b]{2}{*}{$\begin{array}{c}\text { Platelets } \\
\text { per cu. mm. }\end{array}$} \\
\hline & & & $\begin{array}{c}\text { Total } \\
\text { per cu. } \mathrm{mm} .\end{array}$ & $\begin{array}{c}\text { Per cent. } \\
\text { Polymorpho nuclear }\end{array}$ & \\
\hline 1 & Recovered & $12 \cdot 1$ & 9,500 & 68 & $<10,000$ \\
\hline 1 & Fatal & $8 \cdot 6$ & 2,310 & 15 & $<10,000$ \\
\hline 35 & Recovered & $12 \cdot 8$ & 4,000 & 85 & $158,000^{*}$ \\
\hline 17 & Under treatment & $9 \cdot 4$ & 2,430 & 17 & $<10,000$ \\
\hline 6 & Fatal & $9 \cdot 4$ & 4,600 & 65 & 20,000 \\
\hline 3 & Under treatment & $11 \cdot 0$ & 6,000 & 66 & 39,000 \\
\hline
\end{tabular}

III

ASHES NOTED DLRING TREATMENT WITH MYOCRISIN

\begin{tabular}{|c|c|c|c|c|c|}
\hline \multirow{3}{*}{ Dther Drugs at Time of Test } & \multirow{3}{*}{$\begin{array}{l}\text { Time of Test } \\
\text { in Relation to Rash } \\
\text { (days) }\end{array}$} & \multicolumn{4}{|c|}{ Blood Count at Time of Test } \\
\hline & & \multirow[b]{2}{*}{$\underset{(\mathrm{g} . / 100 \mathrm{ml} .)}{\mathrm{Hb}}$} & \multicolumn{2}{|c|}{ WBC } & \multirow[b]{2}{*}{$\begin{array}{l}\text { Platelets } \\
\text { per cu. mm. }\end{array}$} \\
\hline & & & $\begin{array}{c}\text { Total } \\
\text { per cu. mm. }\end{array}$ & $\begin{array}{c}\text { Per cent. } \\
\text { Polymorphonuclear }\end{array}$ & \\
\hline Salicylates & 2 & $15 \cdot 3$ & 6,400 & 67 & 400,000 \\
\hline Phenylbutazone & 5 & $14 \cdot 6$ & 14,410 & 74 & 380,000 \\
\hline $\begin{array}{l}\text { Indocid Phenylbutazone } \\
\text { Salicylates }\end{array}$ & 3 & $12 \cdot 6$ & 9,860 & 76 & 280,000 \\
\hline Salicylates & 1 & $13 \cdot 9$ & 10,520 & 71 & $\mathbf{N}$ \\
\hline Indocid Salicylates & 3 & $11 \cdot 0$ & 9,410 & 58 & $\mathbf{N}$ \\
\hline Salicylates & 7 & $16 \cdot 2$ & 5,830 & 65 & $\mathbf{N}$ \\
\hline
\end{tabular}

$\mathrm{N}=$ normal on film

\section{Patients with Haematological Complications (Group A)}

Cultures from all six patients in this group responded to Myocrisin (Fig. 3 and Table IV, overleaf). In general, the magnitude of the response was similar to that produced by other antigens in positive cultures (Table IV). Cultures from five of these patients did not respond to phenylbutazone or other drugs, irrespective of whether they were receiving them at the time of testing. The sixth patient (Patient 5 in Table IV), who had been given gold injections 12 years earlier, was taking phenylbutazone $300 \mathrm{mg}$. daily when marrow depression developed. Lymphocyte cultures from this patient responded to phenylbutazone as well as to gold.

One patient (Patient 1 in Table IV) was re-tested
4 months later after a course of BAL and steroids, and her blood lymphocytes no longer responded to Myocrisin.

\section{Patient receiving Myocrisin without Side-effects Gold (Group B)}

Cultures from one patient only in this group (Patient 3 in Table III) responded to Myocrisin giving a two-fold response, and none reacted to any other drug.

\section{Patients receiving Myocrisin without Side-effects (Group C)}

Lymphocyte cultures from eleven of twelve patients failed to respond to Myocrisin or any other 


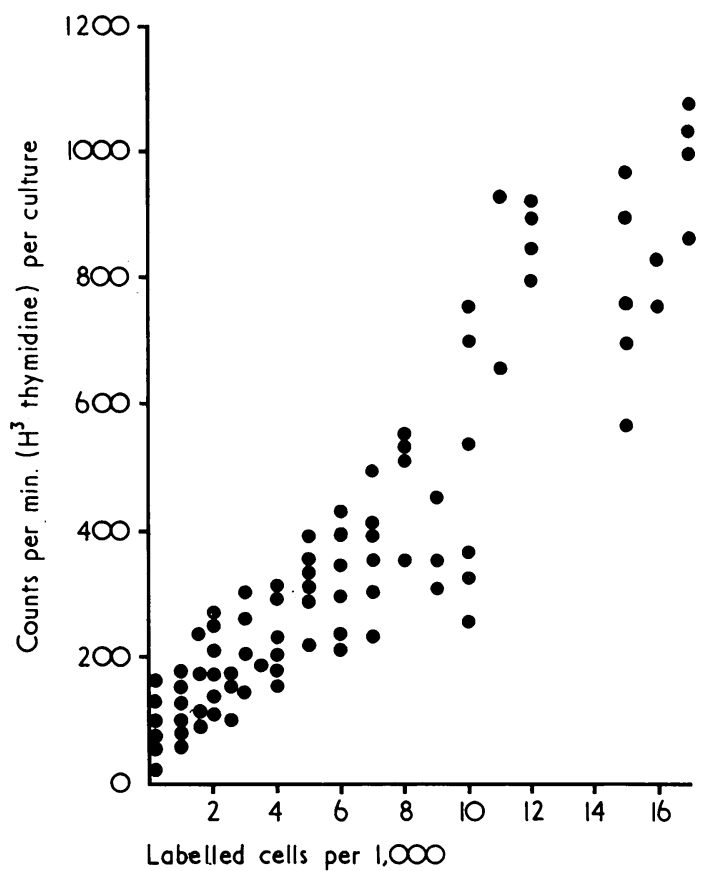

Fig. 2.-Correlation between radioactivity (counts per minute) and labelled blast cells (no. per 1,000) in 84 "baseline" and stimulated $r=0.94$ cultures.

drug. However, cultures from one patient did give a two-fold response to Myocrisin only. This patient, a 12-year-old girl with Still's disease, had been given a total of $642.5 \mathrm{mg}$. Myocrisin in 3 years and was receiving $20 \mathrm{mg}$. injections monthly at the time of testing, but 2 months later she developed an itchy eczematous plaque on the leg lasting one month.

\section{Patients with Rheumatoid Arthritis who had never received Myocrisin (Group D)}

Lymphocyte cultures from these patients responded neither to Myocrisin nor to other drugs.

\section{Discussion}

There has been scant evidence that gold toxicity results from immunologically determined hypersensitivity. Tullis (1958) and Weissmann and Xefteris (1959) described circulating leucoagglutinins in patients with gold toxicity. Denman, Huber, Wood, and Scott (1965) found that marrow depression did not predictably follow the administration of gold salts and concluded that the toxic effects of gold were more likely to be based on individual hypersensitivity.

Human peripheral lymphocytes from sensitized donors have been shown to respond in vitro to

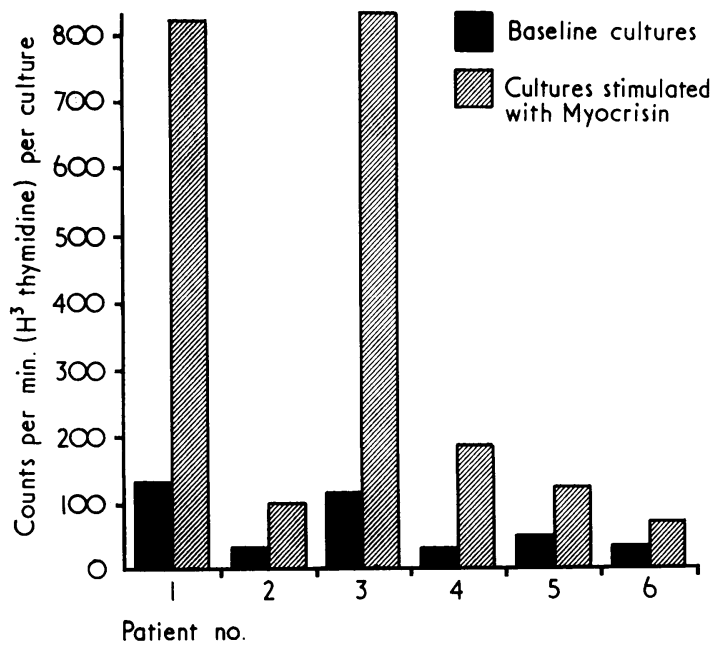

Fig. 3.-Comparison between uptake of $\mathbf{H}^{3}$ thymidine in "baseline" cultures and Myocrisin stimulated cultures in six patients with haematological complications.
The number of each patient corresponds with that in Tables II and IV.

stimulation by the sensitizing antigen with the formation of blast cells which in turn is associated with increased DNA synthesis compared with unstimulated cultures. A variety of antigens has been shown to induce this transformation (Robbins, 1964). Positive tests have been described in patients with penicillin hypersensitivity (Vischer, 1966), and Sarkany (1967) described the use of the lymphocyte transformation test in forty patients with suspected drug hypersensitivity, in seven of whom it was positive. The offending drugs in this series which produced in vitro transformation were sulphonamides, penicillin, PAS, and chlorpropamide. Cultures which did not respond included one from a patient with a suspected gold rash.

We have used the lymphocyte transformation test to provide evidence that idiosyncrasy to Myocrisin is immunologically determined. A positive test was obtained in five patients in whom there was little clinical doubt that Myocrisin was responsible for bone marrow depression. Although the sixth patient had not received Myocrisin for 12 years, this complication can certainly follow several months after the completion of a course of injections with gold salts (Saphir and Ney, 1966) and it is known that gold remains in the tissues for many years after its administration (Edström, 1959; Block and Van Goor, 1956). However, phenylbutazone is known to produce aplastic anaemia (McCarthy and Chalmers, 1964) and this drug was probably responsible, at least in part, for the marrow depression in this patient. It is also possible 
TABLE IV

RESULTS OF LYMPHOCYTE STIMULATION TESTS IN SIX PATIENTS WITH HAEMATOLOGICAL COMPLICATIONS AFTER TREATMENT WITH MYOCRISIN (SAME PATIENTS AS IN TABLE II)

\begin{tabular}{|c|c|c|c|c|c|c|c|c|c|}
\hline \multirow{2}{*}{$\begin{array}{l}\text { Patient } \\
\text { No. }\end{array}$} & \multicolumn{3}{|c|}{$\mathrm{H}^{3}$ Thymidine (c.p.m.) } & \multicolumn{3}{|c|}{$\begin{array}{c}\text { Autoradiographs } \\
\text { Labelled Cells per } 1,000\end{array}$} & \multicolumn{3}{|c|}{$\mathrm{H}^{3}$ Thymidine (c.p.m.) } \\
\hline & Baseline & Myocrisin* & Ratiof & Baseline & Myocrisin & Ratio & Stimulant & c.p.m. & Ratio \\
\hline 1 & 130 & 810 & $6 \cdot 2$ & $1 \cdot 5$ & $10 \cdot 0$ & $6 \cdot 6$ & $\begin{array}{l}\text { BTZ } \\
\text { PPD } \\
\text { Streptokinase } \\
\text { Endotoxin }\end{array}$ & $\begin{array}{r}150 \\
170 \\
1,000 \\
140\end{array}$ & $\begin{array}{l}1 \cdot 1 \\
1 \cdot 3 \\
7 \cdot 7 \\
1 \cdot 1\end{array}$ \\
\hline 2 & 31 & 100 & $3 \cdot 2$ & $1 \cdot 0$ & $2 \cdot 5$ & $2 \cdot 5$ & $\begin{array}{l}\text { BTZ } \\
\text { PPD } \\
\text { Streptokinase } \\
\text { Endotoxin }\end{array}$ & $\begin{array}{l}33 \\
65 \\
35 \\
32 \\
\end{array}$ & $\begin{array}{l}1 \cdot 0 \\
2 \cdot 1 \\
1 \cdot 0 \\
1 \cdot 0\end{array}$ \\
\hline 3 & 114 & 839 & $7 \cdot 3$ & $2 \cdot 0$ & $16 \cdot 0$ & $8 \cdot 0$ & $\begin{array}{l}\text { BTZ } \\
\text { PPD } \\
\text { Streptokinase } \\
\text { Endotoxin }\end{array}$ & $\begin{array}{l}168 \\
268 \\
167 \\
-\end{array}$ & $\begin{array}{l}1 \cdot 4 \\
2 \cdot 3 \\
1 \cdot 4 \\
-\end{array}$ \\
\hline 4 & 30 & 185 & $6 \cdot 1$ & $1 \cdot 0$ & $5 \cdot 5$ & $5 \cdot 5$ & $\begin{array}{l}\text { BTZ } \\
\text { PPD } \\
\text { Streptokinase } \\
\text { Endotoxin }\end{array}$ & $\begin{array}{r}34 \\
60 \\
189 \\
-\end{array}$ & $\begin{array}{l}1 \cdot 0 \\
2 \cdot 0 \\
6 \cdot 3 \\
-\end{array}$ \\
\hline 5 & 48 & 121 & $4 \cdot 6$ & $1 \cdot 0$ & $4 \cdot 0$ & $4 \cdot 0$ & $\begin{array}{l}\text { BTZ } \\
\text { PPD } \\
\text { Streptokinase } \\
\text { Endotoxin }\end{array}$ & $\begin{array}{r}374 \\
120 \\
52 \\
50\end{array}$ & $\begin{array}{l}7 \cdot 7 \\
2 \cdot 5 \\
1 \cdot 1 \\
1 \cdot 0 \\
\end{array}$ \\
\hline 6 & 32 & 69 & $2 \cdot 1$ & - & - & - & $\begin{array}{l}\text { BTZ } \\
\text { PPD } \\
\text { Streptokinase } \\
\text { Endotoxin }\end{array}$ & $\begin{array}{r}35 \\
573 \\
1,570 \\
67\end{array}$ & $\begin{array}{r}1 \cdot 0 \\
17 \cdot 9 \\
49 \cdot 0 \\
2 \cdot 0\end{array}$ \\
\hline
\end{tabular}

c.p.m. $=$ counts per minute. $\quad \mathrm{BTZ}=$ Phenylbutazone. ${ }^{*}$ Cultures to which $10 \mu \mathrm{g}$. and $20 \mu \mathrm{g}$. Myocrisin were added gave similar results. + Ratio = counts per minute or number of labelled cells per 1,000 in stimulated cultures/baseline cultures

Where no result appears, the test was not performed.

that the gold and phenylbutazone acted synergistically (Leonard, 1953).

A positive lymphocyte transformation test was obtained in only one of the six patients who developed skin rashes during Myocrisin therapy. However, it is questionable whether these rashes could in fact be attributed to gold toxicity; indeed the Empire Rheumatism Council (1961) reported that dermatitis developed in seven out of 82 patients who were receiving a placebo. Another explanation might be that this form of hypersensitivity results from a different mechanism from that which causes marrow depression.

The specificity of the response to Myocrisin was demonstrated by the failure of the cultures to respond to other drugs.

A positive transformation test with Myocrisin was obtained in only one of the twelve patients who had not shown clinical evidence of sensitization at the time of testing, and from none of the six patients who had never received gold. Although this one patient may indeed have given a false positive result, it is also possible that the reaction indicated that sensitization was developing in advance of clinically obvious toxicity, particularly as a skin rash subsequently appeared. It is not certain how Myocrisin induced lymphocyte transformation in patients who became sensitized to this drug. It is possible that the response reflects immunological memory in circulating lymphocytes following primary sensitization (Vischer and Stastny, 1967). Alternatively, the sensitized lymphocytes may be concerned in delayed hypersensitivity responses directed at haemopoietic stem cells in the bone marrow (Loewi, Temple, and Vischer, 1968). Which portion of the sodium aurothiomalate molecule provokes this sensitization is also unknown, but presumably part or all of the molecule acts as a hapten after combination with tissue proteins. Studies are in progress to elucidate this problem.

The test would be of greatest value if it could be used to predict the sensitization of patients to Myocrisin before the development of overt toxicity, and this possibility is also being explored.

It is of interest that lymphocyte cultures from patients receiving Myocrisin produced responses to 
PHA and other antigens comparable to those obtained in other patients with rheumatoid arthritis we have studied. This finding recalls the observations of Persellin, Hess, and Ziff (1967), who found that gold salts had no effect on the antibody response to a variety of antigens.

\section{Summary}

Lymphocyte transformation in vitro has been evaluated as a test for hypersensitivity to Myocrisin using liquid scintillation counting and autoradiographic techniques. Positive responses to Myocrisin were obtained in five patients with rheumatoid arthritis who had developed haematological sideeffects after gold therapy and in a sixth with similar complications after gold and phenylbutazone therapy. A positive response was obtained in one out of six patients with rashes associated with gold therapy and in one out of twelve patients who had no clinical evidence of gold toxicity at the time of testing. This one patient in the latter group subsequently developed a rash. Negative results were obtained with other drugs, except in one patient who developed aplastic anaemia after gold and phenylbutazone therapy who responded to these but not to other drugs. All the patients studied responded normally to phytohaemagglutinin and other antigens.

The value of this test in the diagnosis and prediction of gold toxicity is discussed. These findings indicate that some, at least, of the toxicity produced by gold may be immunologically determined.

The authors are grateful to Prof. E. G. L. Bywaters for his interest and encouragement, to Dr. Thomas Vischer for his advice and many stimulating discussions, and to Mr. P. Fiske for help with the preparation of autoradiographs.

\section{REFERENCES}

Block, W. D., and Van Goor, K. (1956). "Metabolism, Pharmacology and Therapeutic Uses of Gold Compounds". (American Lecture Series Publication No. 282). Thomas, Springfield, Ill.

Bray, G. A. (1960). Analyt. Biochem., 1, 279 (A simple efficient liquid scintillator for counting aqueous solutions in a liquid scintillation counter).

Denman, A. M., Huber, H., Wood, P. H. N., and Scott, J. T. (1965). Ann. rheum. Dis., 24, 278 (Reticulocyte count in patients with rheumatoid arthritis, with observations on the effect of gold therapy on bone marrow function).

Empire Rheumatism Council (1960). Ibid., 19, 95 (Gold therapy in rheumatoid arthritis).

- (1961). Ibid., 20, 335 (Relation of toxic reactions in gold therapy to improvement in rheumatoid arthritis).

Edström, G. (1959). Acta rheum. scand., 5, 53 (Value and complications of gold therapy in rheumatoid arthritis).

Loewi, G., Temple, A., and Vischer, T. L. (1968). Immunology, 14, 257 (The immunological significance in the guinea-pig of in vitro transformation of lymph node, spleen and peripheral blood lymphocytes).

Leonard, J. C. (1953). Brit. med. J., 1, 1311 (Toxic effects of phenylbutazone with special reference to disorders of the blood).

McCarthy, D. D., and Chalmers, T. M. (1964). Canad. med. Ass. J., 90, 1061 (Hematological complications of phenylbutazone therapy: review of the literature and report of two cases).

Persellin, R. H., Hess, E. V., and Ziff, M. (1967). Arthr. and Rheum., 10, 99 (Effect of a gold salt on the immune response).

Robbins, J. H. (1964). Science, 146, 1648 (Tissue culture studies of the human lymphocyte).

Saphir, J. R., and Ney, R. G. (1966). J. Amer. med. Ass., 195, 782 (Delayed thrombocytopenic purpura after diminutive gold therapy).

Sarkany, I. (1967). Lancet, 1, 743 (Lymphocyte transformation in drug hypersensitivity).

Tullis, J. L. (1958). New Engl. J. Med., 258, 569 (Prevalence, nature and identification of leukocyte antibodies).

Vischer, T. L. (1966). Lancet, 2, 467 (Lymphocyte cultures in drug hypersensitivity).

- and Stastny, P. (1967). Immunology, 12, 675 (Time of appearance and distribution of cells capable of secondary immune response following primary immunization).

Weissmann, G., and Xefteris, E. D. (1959). A.M.A. Arch. intern. Med., 103, 957 (Phenylbutazone leukopenia). 
Le test de la transformation des lymphocytes et l'hypersensibilité aux sels d'or

\section{RÉSUMÉ}

La transformation des lymphocytes in vitro a été évaluée comme test de l'hypersensibilité à la Myocrisine en se servant de la numération de la scintillation liquide et par l'autoradiographie. Les résultats positifs à la Myocrisine avaient été obtenus chez cinq malades atteints de polyarthrite rhumatoïde qui avaient développé des effets hématologiques secondaires après un traitement avec de l'or et chez un sixième malade qui avait eu des complications semblables après un traitement avec de l'or et de la phénylbutazone. Un résultat positif avait été obtenu chez un des six malades qui avait eu une éruption cutanée associée au traitement avec de l'or et chez un des douze malades qui n'avait pas donné de signes cliniques de toxicité avec l'or au moment ou le test avait été fait. Ce malade du dernier groupe avait subséquemment développé une éruption sous-cutanée. Des résultats négatifs avaient été obtenus avec d'autres médicaments, excepté chez un malade qui avait développé une anémie aplastique après le traitement avec de l'or et de la phénylbutazone et qui avait réagi à ce traitement mais pas à d'autres médicaments. Tous les malades qui ont fait partie de cette étude avaient réagi normalement à la phytohémagglutinine et à d'autres antiègnes.

La valeur de ce test dans le diagnostic et la prédiction de toxicité à l'or est discutée. Ces constatations indiquent qu'une partie au moins de la toxicité produite par l'or peut être déterminée immunologiquement.
La prueba de transformación linfocitaria y la hipersensibilidad al oro

\section{SUMARIO}

Se evaluó la transformación linforcitaria in vitro como prueba para la hipersensibilidad a la Miocrisina, empleandose las técnicas de centelleoscopía en líquido y autoradiografía. Se obtuvieron reacciones positivas a la Miocrisina en cinco pacientes reumáticos después de la crisoterapía, y también en un paciente adicional que experimentó complicaciones parecidas después de tratamiento con el oro y la fenilbutazona. Se obtuvieron reacciones positivas en uno de seis pacientes con erupciones cutaneas causadas por crisoterapía y en uno de 12 pacientes que no manifestaban evidencia de intoxicación por el oro al tiempo de la investigación. Con otras drogas se obtuvieron reacciones negativas, salvo en un paciente que tuvo una anemia aplástica después de ser tratado con el oro y la fenilbutazona; estas dos drogas, pero no otras, provocaron una reacción positiva en este caso. Todos los pacientes investigados reaccionaron normalmente a la fitohemaglutinina y otros antígenos.

Se discute el valor de esta prueba para el diagnosis y la predicción de la intoxicacion por el oro. Los resultados manifiestan que por lo menos alguna parte de la toxicidad que produce el oro puede atribuirse a mecanismos inmunológicos. 